\title{
Article
}

\section{In Situ Transesterification of Microbial Biomass for Biolubricant Production Catalyzed by Heteropolyacid Supported on Niobium}

\author{
Savienne M. F. E. Zorn ${ }^{1, * \mathbb{D}}$, Ana Paula T. da Silva ${ }^{1}$, Eduardo H. Bredda ${ }^{2} \mathbb{D}$, Heitor B. S. Bento ${ }^{3}$, \\ Guilherme A. Pedro ${ }^{1} \mathbb{D}$, Ana Karine F. Carvalho ${ }^{1,4}$, Messias Borges Silva ${ }^{1,2} \mathbb{D}$ and Patrícia C. M. Da Rós ${ }^{1} \mathbb{D}$
}

\section{check for}

updates

Citation: Zorn, S.M.F.E.; da Silva, A.P.T.; Bredda, E.H.; Bento, H.B.S.; Pedro, G.A.; Carvalho, A.K.F.; Silva, M.B.; Da Rós, P.C.M. In Situ Transesterification of Microbial Biomass for Biolubricant Production Catalyzed by Heteropolyacid Supported on Niobium. Energies 2022, 15, 1591. https://doi.org/ 10.3390/en15041591

Academic Editor: Attilio Converti

Received: 17 January 2022

Accepted: 17 February 2022

Published: 21 February 2022

Publisher's Note: MDPI stays neutral with regard to jurisdictional claims in published maps and institutional affiliations.

Copyright: (c) 2022 by the authors. Licensee MDPI, Basel, Switzerland. This article is an open access article distributed under the terms and conditions of the Creative Commons Attribution (CC BY) license (https:// creativecommons.org/licenses/by/ $4.0 /)$.
1 Engineering School of Lorena, University of São Paulo, Lorena 12602-810, Brazil; eng.ana.teixeira@usp.br (A.P.T.d.S.); guilhermepedro@usp.br (G.A.P.); ana.furtado@unifal-mg.edu.br (A.K.F.C.); messias.silva@unesp.br (M.B.S.); patriciadaros@usp.br (P.C.M.D.R.)

2 Engineering Faculty of Guaratinguetá, São Paulo State University (UNESP), Guaratinguetá 12516-410, Brazil; eduardobredda@gmail.com

3 Bioprocess Engineering and Biotechnology, Faculty of Pharmaceutical Sciences, São Paulo State University (UNESP), Araraquara 14800-903, Brazil; heitor.bento@unesp.br

4 Postgraduate Program in Biotechnology, Chemistry Institute, Federal University of Alfenas, Alfenas 37130-001, Brazil

* Correspondence: savienne.elerbrock@usp.br; Tel.: +55-012-3159-5149

\begin{abstract}
Lubricants are substances of the foremost importance in the modern world, as they are essential to the proper functioning of various mechanisms. Most lubricants, however, are still made from petroleum fractions. I light of this, and due to various environmental problems, the search for feasible biolubricants has become essential. This study obtained biolubricants through the in situ transesterification of microbial biomass, containing at least $20 \mathrm{wt} \%$ of lipids. The following two distinct biomasses were evaluated: the marine microalgae, Dunaliella salina, and the consortium of microalgae-fungi, Scenedesmus obliquus and Mucor circinelloides. Microbial oil from both biomasses presented a fatty acid profile with high amounts of oleic acid. The oil of $D$. salina had a lower content of polyunsaturated fatty acids relative to the microbial consortium profile, which indicates that this is a good configuration for increasing biolubricant oxidation resistance. The catalyst used was a Keggin-structure heteropolyacid supported on niobium, $\mathrm{H}_{3} \mathrm{PMo}_{12} \mathrm{O}_{40} / \mathrm{Nb}_{2} \mathrm{O}_{5}$, activated at $150{ }^{\circ} \mathrm{C}$, which had high transesterification yields, notwithstanding the feedstocks, which were rich in free fatty acids. The performed transesterification reactions resulted in excellent yields, up to $97.58 \%$ and $96.80 \%$, for marine microalgae and the consortium, respectively, after $6 \mathrm{~h}$ at $250{ }^{\circ} \mathrm{C}$, with $10 \mathrm{wt} \%$ of catalyst (related to the lipid amount). As such, the $\left(\mathrm{H}_{3} \mathrm{PMo}_{12} \mathrm{O}_{40} / \mathrm{Nb}_{2} \mathrm{O}_{5}\right)$ catalyst could become an attractive option for producing biolubricants from microbial biomass.
\end{abstract}

Keywords: biolubricant; $\mathrm{H}_{3} \mathrm{PMo}_{12} \mathrm{O}_{40}$; microbial biomass; fusel oil; microalgae; consortium; Dunaliella salina; Scenedesmus obliquus; Mucor circinelloides

\section{Introduction}

Lubricants are described as substances that are put on machines, or parts of machines, for the purpose of alleviating friction. Applying lubricant smooths the movements of various types of mechanisms, preventing frictional heat release, and the erosion of moving parts [1,2]. Additionally, lubricants help reduce oxidation and act as a sealing solution against dirt and water. It should be of no surprise that lubricant use is increasing around the world, since, for the next seven years, an estimated market increase of $3.7 \%$ per year has been predicted [3].

A concerning problem, however, is that most lubricants in popular use are still made from petroleum fractions. When such products are inappropriately discarded, they cause huge environmental problems, with soil, water, and air contamination. In light of these 
issues, biolubricants could be an attractive alternative, as they have high biodegradability, low toxicity, and can be made of various renewable sources $[1,2,4]$.

From the many diverse sources available to produce biolubricants, vegetable oils are the most practical option $[1,2,4]$. Despite that, microalgae oil is also an interesting choice to produce biolubricants, as it does not compete with the food industry for supply, as vegetable oils would. Moreover, many kinds of vegetable oils have excessive amounts of polyunsaturated fatty acids. This oil composition reduces the thermal stability of the resulting biolubricant $[5,6]$. Microalgae oil, on the other hand, has different kinds of composition, depending on the microalgae species, and cultivation parameters [7-9]. Bredda et al. [10], for instance, using different light colors to illuminate a Dunaliella salina cultivation, obtained microalgae oil with high productivity. The lipids obtained by the authors were rich in oleic acid, C18:1, with very low contents of linoleic and linolenic acids, C18:2 and C18:3, respectively. This specific composition makes the microalgae oil, obtained by Bredda et al. [10], an excellent candidate for the production of biolubricants $[5,6]$.

Another source of microbial oil comes from the consortia formed by two distinct species. The fatty acid profile of the microbial consortium composed of the species Chlorella vulgaris and Mucor circinelloides was studied by Zorn et al. [11]. The microbial oil presented around $35 \%$ oleic acid (C18:1), 12\% linoleic acid (C18:2), and 15\% linolenic acid (C18:3). Although polyunsaturated acids represent about $26.7 \%$ of this composition, the synthesis of biolubricants may be possible, considering the high content of oleic acid.

Microalgae biomass can be used as raw material for biolubricant production via the transesterification of triglycerides present in its oil. The transesterification reaction is, essentially, the transformation of one ester into another. For biolubricant production, the triacylglycerol of the microalgae oil reacts with one or more alcohols, producing a mixture of fatty esters (biolubricant). The alcohol molecules act as acyl receptors in the transesterification reaction [1,4,12]. Therefore, choosing an appropriate acyl receptor is of immense importance to the final properties of the produced biolubricant, and for the transesterification yield.

This production procedure can be performed in one or two stages. The two steps approach is made by the transesterification of the triglycerides with methanol or ethanol, producing methyl or ethyl esters, respectively. Those products, then, react with a polyol (e.g., trimethylolpropane, pentaerythritol, and neopentyl glycol), producing the biolubricant. The first stage is necessary to reduce the viscosity of the triglycerides, accelerating the second stage of the process, favoring the purification of the biolubricant. This has been one of the main routes to produce biolubricants [1].

Obtaining biolubricants with a single step, however, is possible, which can reduce production costs. Da Silva et al. [4], for instance, achieved high transesterification yields with single-step transesterification, using fusel oil as acyl receptor. This method establishes fusel oil as an interesting choice among acyl receptors. Fusel oil is a byproduct generated in the multistage distillation of ethanol, which was obtained through fermentation. It is mainly composed of alcohols with two to five carbon atoms per molecule (e.g., ethanol, n-propyl alcohol, isoamyl alcohol, isobutyl alcohol, and n-butyl alcohol) [13,14]. The use and proper disposal of fusel oil, as a chemical residue, is of immense importance, economically and environmentally speaking. This is reinforced by the increasing demand for pure alcohol, provoked by the COVID-19 pandemic, which greatly increased the production of fusel oil [13].

Yet, to make the transesterification of microalgae oil a feasible method of producing biolubricants, a proper catalyst must be chosen. Of the variety available, heteropolyacid catalysts were considered with great interest, both in industrial fields and in academic research, due to their high versatility [15]. $\mathrm{H}_{3} \mathrm{PMo}_{12} \mathrm{O}_{40}$, a heteropolyacid with a Keggin-structure, oxide supported on niobia $\left(\mathrm{Nb}_{2} \mathrm{O}_{5}\right)$ has been reported to achieve high transesterification yields, even with lipids containing high amounts of free fatty acids $[15,16]$. In addition, this catalyst $\left(\mathrm{H}_{3} \mathrm{PMo}_{12} \mathrm{O}_{40} / \mathrm{Nb}_{2} \mathrm{O}_{5}\right)$ can be extracted at the end of the reaction and used again with a low loss of activity; it has two reuse cycles, increasing the process' feasibility. 
Another important parameter to be taken into consideration when developing a feasible microalgae-based bioprocess is the harvesting method. In addition to microbial consortia being able to generate a lipid-rich biomass, forming a composite biomass is achievable via a simple, low-cost, and sustainable method. To elaborate, using filamentous fungi to support the aggregation of microalgae cells has been highlighted as a method that generates lichen-like structures with elevated harvesting yields. Therefore, the microalgaefungi consortium may contribute to a decrease in the global cost of algae-based biolubricant production [11,17].

Microalgae Scenedesmus obliquus and C. vulgaris have many characteristics in common. Both species are freshwater, colonial, lipid producers, and fast-growing [18-20]. Based on the previous work done in [11], the freshwater species Scenedesmus obliquus was applied in the composition of a microbial consortium with the filamentous fungus Mucor circinelloides, also presenting a fatty acid profile rich in oleic acid (29.69\% average).

Considering previous studies, the present study aimed to evaluate the microalgae oil from Dunaliella salina and the oil of a microalgae-fungi consortium composed by Scenedesmus obliquus and Mucor circinelloides as feedstock for biolubricant synthesis, using the following as acyl receptors: fusel oil components (ethanol, butanol, and isoamyl alcohol) and simulated fusel oil. The catalyst chosen was the heteropolyacid $\mathrm{H}_{3} \mathrm{PMo}_{12} \mathrm{O}_{40}$ oxide-supported $\left(\mathrm{Nb}_{2} \mathrm{O}_{5}\right)$.

\section{Materials and Methods}

Marine microalgae Dunaliella salina (BMAK 116), from the Seaweed Culture Collection (Oceanographic Institute-University of São Paulo), was kindly provided by the Department of Biological Oceanography (São Paulo, Brazil). The oil of Acrocomia aculeata (macaw palm oil) was supplied by the Association of Small Farmers D'Antas (Minas Gerais, Brazil).

Microbial consortium composition: filamentous fungus Mucor circinelloides $\mathrm{f}$. griseo-cyanus URM 4182 was obtained at Federal University of Pernambuco, Recife, Brazil, and freshwater microalgae Scenedesmus obliquus CCMA-UFSCar 604-was purchased from the Federal University of São Carlos, Brazil.

Other chemicals are of an analytic degree.

\subsection{Cultivation of Microalgae}

Marine microalgae cultivations were conducted in bubble column photobioreactors (internal diameter of $150 \mathrm{~mm}$, height of $1000 \mathrm{~mm}$, and $5.0 \mathrm{~mm}$ wall thickness) with $10 \mathrm{~L}$ working volume, inoculated at $20 \%(v / v)$. The cultivations were kept for a duration of seven days at $25 \pm 1{ }^{\circ} \mathrm{C}$, under white LED light (150 klux of intensity).

Dunaliella salina (D. salina) was cultivated in Guillard f/ 2 culture media, supplemented with $\mathrm{NaNO}_{3}$ (225 mg L $\left.{ }^{-1}\right)$ and sodium acetate $\left(4 \mathrm{~g} \mathrm{~L}^{-1}\right)$, according to Bredda et al. [10].

Microalgae biomass harvesting occurred after flocculation, by adding $1 \mathrm{~mol} \mathrm{~L}^{-1}$ aluminum sulfate solution to the culture, followed by centrifugation (3000 RPM, 15 min) and washing with distilled water.

Vacuum filtration was carried out to remove excess water and biomass stored at $-5{ }^{\circ} \mathrm{C}$ until use in the in situ transesterification reactions.

\subsection{Cultivation of Microalgae-Fungi Consortium}

As a first step, filamentous fungus spores and algal cells were incubated separately in different culture media, suitable for the growth of each species. Fungus spores were grown in Erlenmeyer flasks (250 mL), with $50 \mathrm{~mL}$ of culture medium A [21] per flask, composed of the following: glucose $\left(2 \mathrm{~g} \mathrm{~L}^{-1}\right), \mathrm{KNO}_{3}\left(1 \mathrm{~g} \mathrm{~L}^{-1}\right), \mathrm{KH}_{2} \mathrm{PO}_{4}\left(0.075 \mathrm{~g} \mathrm{~L}^{-1}\right), \mathrm{K}_{2} \mathrm{HPO}_{4}(0.1$ $\left.\mathrm{g} \mathrm{L}^{-1}\right), \mathrm{MgSO}_{4} \cdot 2 \mathrm{H}_{2} \mathrm{O}\left(0.5 \mathrm{~g} \mathrm{~L}^{-1}\right), \mathrm{Ca}\left(\mathrm{NO}_{3}\right)_{2} \cdot 4 \mathrm{H}_{2} \mathrm{O}\left(0.0625 \mathrm{~g} \mathrm{~L}^{-1}\right), \mathrm{FeSO}_{4} \cdot 7 \mathrm{H}_{2} \mathrm{O}(0.01 \mathrm{~g}$ $\left.\mathrm{L}^{-1}\right)$, and yeast extract $\left(0.5 \mathrm{~g} \mathrm{~L}^{-1}\right)$; a metal solution $\left(1 \mathrm{~mL} \mathrm{~L}^{-1}\right)$ composed of the following: $\mathrm{H}_{3} \mathrm{BO}_{3}\left(2.86 \mathrm{~g} \mathrm{~L}^{-1}\right), \mathrm{Na}_{2} \mathrm{MoO}_{4} .2 \mathrm{H}_{2} \mathrm{O}\left(0.39 \mathrm{~g} \mathrm{~L}^{-1}\right), \mathrm{ZnSO}_{4} \cdot 7 \mathrm{H}_{2} \mathrm{O}\left(0.22 \mathrm{~g} \mathrm{~L}^{-1}\right), \mathrm{MnCl}_{2} \cdot 4 \mathrm{H}_{2} \mathrm{O}$ $\left(1.81 \mathrm{~g} \mathrm{~L}^{-1}\right), \mathrm{CuSO}_{4} \cdot 5 \mathrm{H}_{2} \mathrm{O}\left(0.079 \mathrm{~g} \mathrm{~L}^{-1}\right)$, and $\mathrm{Co}\left(\mathrm{NO}_{3}\right)_{2} \cdot 6 \mathrm{H}_{2} \mathrm{O}\left(0.049 \mathrm{~g} \mathrm{~L}^{-1}\right)$. 
WC culture medium [22] was used for microalgae cells, composed of the following: $\mathrm{CaCl}_{2} \cdot 2 \mathrm{H}_{2} \mathrm{O}\left(36.76 \mathrm{mg} \mathrm{L}^{-1}\right), \mathrm{MgSO}_{4} \cdot 7 \mathrm{H}_{2} \mathrm{O}\left(36.97 \mathrm{mg} \mathrm{L}^{-1}\right), \mathrm{NaHCO}_{3}\left(12.60 \mathrm{mg} \mathrm{L}^{-1}\right)$, $\mathrm{K}_{2} \mathrm{HPO}_{4}\left(8.71 \mathrm{mg} \mathrm{L}^{-1}\right)$, and $\mathrm{NaNO}_{3}\left(85.01 \mathrm{mg} \mathrm{L}^{-1}\right)$; a metal solution composed of the following: $\mathrm{Na}_{2}$ EDTA $\left(4.36 \mathrm{mg} \mathrm{L}^{-1}\right), \mathrm{FeCl}_{3} \cdot 6 \mathrm{H}_{2} \mathrm{O}\left(3.15 \mathrm{mg} \mathrm{L}^{-1}\right), \mathrm{CuSO}_{4} \cdot 5 \mathrm{H}_{2} \mathrm{O}\left(0.01 \mathrm{mg} \mathrm{L}^{-1}\right)$, $\mathrm{ZnSO}_{4} \cdot 7 \mathrm{H}_{2} \mathrm{O}\left(0.022 \mathrm{mg} \mathrm{L}^{-1}\right), \mathrm{CoCl}_{2} \cdot 6 \mathrm{H}_{2} \mathrm{O}\left(0.01 \mathrm{mg} \mathrm{L}^{-1}\right), \mathrm{MnCl}_{2} \cdot 4 \mathrm{H}_{2} \mathrm{O}\left(0.18 \mathrm{mg} \mathrm{L}^{-1}\right)$, $\mathrm{Na}_{2} \mathrm{MoO}_{4} \cdot 2 \mathrm{H}_{2} \mathrm{O}\left(0.006 \mathrm{mg} \mathrm{L}^{-1}\right), \mathrm{H}_{3} \mathrm{BO}_{3}\left(1.0 \mathrm{mg} \mathrm{L}^{-1}\right)$, and a solution of vitamins consisting of Thiamine $\left(0.1 \mathrm{mg} \mathrm{L}^{-1}\right)$, Biotin $\left(0.5 \mu \mathrm{g} \mathrm{L}^{-1}\right)$, and Cobalamin $\left(0.5 \mu \mathrm{g} \mathrm{L}^{-1}\right)$.

Erlenmeyer flasks $(500 \mathrm{~mL})$, with $100 \mathrm{~mL}$ WC medium, were used for microalgae cell cultures. Sugarcane molasses $\left(0.6 \mathrm{~g} \mathrm{~L}^{-1}\right)$ were added to the WC culture medium, as a supplement. Culture medium A $(50 \mathrm{~mL})$ was inoculated with $4.25 \times 10^{5}$ spores and the WC medium $(100 \mathrm{~mL})$ was inoculated with $2.55 \times 10^{8}$ microalgae cells. Flasks were incubated separately for $72 \mathrm{~h}$ in different orbital shakers; fungal cultures at $250 \mathrm{rpm}, 26 \pm 1{ }^{\circ} \mathrm{C}$, and microalgae cultures at $140 \mathrm{rpm}, 25 \pm 1{ }^{\circ} \mathrm{C}$, with microalgae cultures under constant white led illumination $\left(150 \mu \mathrm{mol} \cdot \mathrm{m}^{-2} \cdot \mathrm{s}^{-1}\right)$.

In a second step, each of the fungal mycelia was harvested by filtration. Two fungal mycelia were added to each flask containing microalgae cell cultures and the incubation continued for another $108 \mathrm{~h}$; at the end of this period, the biomass of the consortia was collected by filtration.

All analyses were conducted in triplicate.

\subsection{Catalyst: Synthesis and Surface Acidity}

The heteropolyacid $\left(\mathrm{H}_{3} \mathrm{PMo}_{12} \mathrm{O}_{40}\right)$ oxide-supported $\left(\mathrm{Nb}_{2} \mathrm{O}_{5}\right)$ was prepared using the incipient-wetness impregnation method, described by da Conceição et al. [16]. $0.6 \mathrm{~g}$ of the heteropolyacid catalyst were dissolved in $0.72 \mathrm{~mL}$ of alcohol solution $(70 \%)$ at room temperature. The obtained suspension was mixed with $2.0 \mathrm{~g}$ of support $\left(\mathrm{Nb}_{2} \mathrm{O}_{5}\right)$ in order to achieve a final catalyst concentration of $30 \mathrm{wt} \%$. The obtained solid was dried at $100{ }^{\circ} \mathrm{C}$ for $30 \mathrm{~min}$ and calcinated afterward. The calcination procedure was performed in two steps, both under a $300{ }^{\circ} \mathrm{C}$ temperature. The first step lasted $1 \mathrm{~h}$, and the second one, $3 \mathrm{~h}$.

Acid-base titrations were used to determine the catalyst surface acidity. In a typical measurement, $0.1 \mathrm{~g}$ of solid was suspended in $20 \mathrm{~mL}$ of $0.1 \mathrm{~mol} \mathrm{~L}^{-1} \mathrm{NaOH}$. The suspension was stirred for $3 \mathrm{~h}$ at $25{ }^{\circ} \mathrm{C}$ and titrated with $0.1 \mathrm{~mol} \mathrm{~L}^{-1} \mathrm{HCl}$ in the presence of phenolphthalein. The surface acidity of the catalyst was expressed in the $\mathrm{mmol} \mathrm{H}^{+} / \mathrm{g}$ catalyst, according to da Conceição [16].

\subsection{Direct Transesterification Reactions and Biolubricant Production}

The in situ transesterifications of the microalgae and microbial consortium biomasses (containing at least $20 \mathrm{wt} \%$ of lipids) were both performed with the $\mathrm{H}_{3} \mathrm{PMo}_{12} \mathrm{O}_{40} / \mathrm{Nb}_{2} \mathrm{O}_{5}$ catalyst (previously activated at $150^{\circ} \mathrm{C}$ for $2 \mathrm{~h}$ ) in a pressurized stainless-steel reactor (Parr Series 5500 HPCL Compact Reactors).

The reaction media comprised $10 \mathrm{wt} \%$ of the catalyst, relating to the lipid present in the biomass. All reactions were performed at $250{ }^{\circ} \mathrm{C}$ and $300 \mathrm{rpm}$ agitation for $6 \mathrm{~h}$. Hexane was used as a solvent $(40 \% v / v)$. Ethanol, butanol, isoamyl acid, synthetic fusel oil, and fusel oil were evaluated as acyl group acceptors. The oil/acyl group acceptor molar ratio was fixed at 1:180.

\subsection{Purification of Biolubricants}

Crude biolubricants were purified using the adsorbent Amberlite BD10DRY, according to the method described by Santos et al. [23].

The samples of crude biolubricant and the Amberlite were transferred to $50 \mathrm{~mL}$ Falcon tubes and placed in an ultrasound bath for $2 \mathrm{~h}$. Then, the samples were centrifuged $(1570 \times \mathrm{g}$ for $15 \mathrm{~min})$ and the residual solvent was removed in a rotary evaporator at $80^{\circ} \mathrm{C}$ for $30 \mathrm{~min}$. 


\subsection{Analytical Procedures}

The esters' content was evaluated by proton nuclear magnetic resonance spectrometry (H NMR) in a Mercury $300 \mathrm{MHz}$-Varian spectrometer, with $5 \mathrm{~mm}$ glass tubes, using $\mathrm{CDCl}_{3}$ as a solvent and $0.3 \%$ tetramethylsilane (TMS) as an internal standard.

Residual glycerides (monoacylglycerol-MAG, and diacylglycerol-DAG) were analyzed by an Agilent 1200 series HPLC (Agilent Technologies, USA) equipped with an evaporative

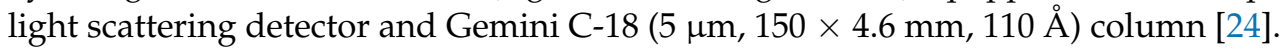

Viscosity was measured at $40{ }^{\circ} \mathrm{C}$, using a Brookfield LVDV-II viscometer (Brookfield Viscometers Ltd., England, UK) [4,24,25]. A circulating water bath was used to maintain the temperature in each analysis at $40{ }^{\circ} \mathrm{C}$. The shear stress measurements were taken as a function of shear rate and the dynamic viscosity was determined as a slope constant. Samples of $0.5 \mathrm{~mL}$ were used and the measurements were replicated three times.

The extraction of the lipids in the biomass samples were performed in a digestion system irradiating the microwave region (CEM Discover DU-8081) using $50 \mathrm{~mL}$ of ethanol (vol. 96\%) as an extraction solvent, at temperature $60^{\circ} \mathrm{C}$, three cycles of $30 \mathrm{~min}$, according to Carvalho et al. [26].

The fatty acid composition was determined via methylation of lipids using a $\mathrm{BF}_{3} /$ methanol mixture following an adaptation to the AOCS Ce 1-62 method. The fatty acid methyl esters (FAMEs) were identified via gas chromatography (GC) analysis using a PerkinElmer ${ }^{\circledR}$-Clarus 580 chromatograph, equipped with a flame ionization detector. A 30-m capillary column with a 0.25-mm internal diameter and 5\% diphenyl 95\% dimethylpolysiloxane stationary phase (non-polar) was used for GC analysis. Nitrogen was the carrier gas $\left(1 \mathrm{~mL} \mathrm{~min}^{-1}\right)$. The identification of methyl esters was carried out by comparing the retention times with a MIX Supelco ${ }^{\circledR}$ Fatty Acid Methyl Acid (FAME). Standard capric acid (C6:0) to lignoceric acid (C24:0) quantification was performed by normalizing the calculated areas. After obtaining the complete fatty acid composition, the fatty acids were grouped into saturated (SFA), monounsaturated (MUFA), and polyunsaturated fatty acids (PUFA), with the percentages of each group calculated in relation to the total.

\section{Results}

\subsection{Growth Parameters and Characterization of Microalgae Oil}

Cultivations of Dunaliella salina (D. salina) were conducted to obtain sufficient microalgal biomass for biolubricant synthesis, as well as to obtain biomass from the microbial consortium. Nine cultivations (90 L of growth medium) of D. salina were used to obtain sufficient microalgal biomass for biolubricant synthesis. A total of $103.50 \mathrm{~g}$ of biomass and $19.66 \mathrm{~g}$ of microalgal oil were obtained. Table 1 shows the growth and production parameters of both the microalgae, D. salina, and the microalgae-fungus consortium, S. obliquus-M. circinelloides.

Table 1. Growth parameters and fatty acid profile: Dunaliella salina and microbial consortium Scenedesmus obliquus/Mucor circinelloides.

\begin{tabular}{ccc}
\hline Growth Parameters & D. Salina & $\begin{array}{c}\text { Microbial } \\
\text { Consortium }\end{array}$ \\
\hline Biomass concentration $\left(\mathrm{g} \mathrm{L}^{-1}\right)$ & $1.15 \pm 0.40$ & $1.27 \pm 0.7$ \\
Lipid concentration $\left(\mathrm{mg} \mathrm{L}^{-1}\right)$ & $219 \pm 0.30$ & $482.6 \pm 0.3$ \\
Lipid yield (mg lipids $\mathrm{mg}^{-1} \mathrm{biomass}^{-}$ & $0.19 \pm 0.10$ & $0.38 \pm 0.3$ \\
Volumetric lipid production rate $\left(\mathrm{mg} \mathrm{L}^{-1} \mathrm{day}^{-1}\right)$ & $31.28 \pm 0.30$ & $64.4 \pm 0.5$ \\
Volumetric biomass production rate $\left(\mathrm{mg} \mathrm{L}^{-1}\right.$ day $\left.^{-1}\right)$ & $164.28 \pm 0.10$ & $169.3 \pm 0.4$ \\
\hline Fatty Acid Groups (wt\%) & & \\
\hline SFA (saturated fatty acids) & 34.27 & 33.69 \\
MUFA (monounsaturated fatty acids) & 46.74 & 34.23 \\
PUFA (polyunsaturated fatty acids) & 18.99 & 32.08 \\
\hline
\end{tabular}


According to Table 1, D. salina oil had a high content of saturated $(34.27 \%)$ and monounsaturated fatty acids (46.74\%), and a low content of polyunsaturated fatty acids $(18.99 \%)$. This fatty acid profile indicates good oxidative stability and the potential of D. salina oil for use in transesterification reactions. D. salina oil had a similar fatty acid profile and physicochemical properties, such as viscosity $\left(60.1 \mathrm{~mm}^{2} \mathrm{~s}^{-1}\right)$, density $\left(0.89 \mathrm{~g} \mathrm{~mL}^{-1}\right)$, and acid value (43.27 $\mathrm{mg} \mathrm{KOH} \mathrm{g}^{-1}$ ), to macaw palm oil [4]. All these properties were determined at $40{ }^{\circ} \mathrm{C}$, according to da Silva et al. [4].

The lipids of the microbial consortium are composed of the relevant content of saturated $(33.69 \%)$ and monounsaturated fatty acids (34.23\%), while polyunsaturated fatty acids correspond to $32.08 \%$. In comparison to the lipids of the D. salina species, the fatty acid composition of the microbial consortium presents a more balanced distribution. However, considering that oleic acid (C18:1) stands out as the main contributor among monounsaturated fatty acids (29.69\% on average), this composition may still be promising for the generation of biolubricants.

\subsection{Catalyst Activity}

Acidity is one of the most important properties of catalysts used in transesterification reactions, which is directly related to their activity. For the heteropolyacid catalysts, specifically, the acidity also indicates if the catalyst impregnation on the support was successful. The acidity of the finished catalyst $\left(\mathrm{H}_{3} \mathrm{PMo}_{12} \mathrm{O}_{40} / \mathrm{Nb}_{2} \mathrm{O}_{5}\right)$ of $5.644 \mathrm{mmol} \mathrm{H}^{+} \mathrm{g}^{-1}$ is quite different from that of the oxide, $\mathrm{Nb}_{2} \mathrm{O}_{5},\left(0.041 \mathrm{mmol} \mathrm{H}^{+} \mathrm{g}^{-1}\right)$. Such a difference is convincing evidence that the impregnation was effective and that effective catalyst activity is to be expected.

This specific heteropolyacid catalyst $\left(\mathrm{H}_{3} \mathrm{PMo}_{12} \mathrm{O}_{40} / \mathrm{Nb}_{2} \mathrm{O}_{5}\right)$ was previously characterized, and the results are presented by da Conceição et al. in ref. [16].

\subsection{Biolubricant Synthesis Catalyzed by Keggin-Structure Heteropolyacid Supported on Niobia}

To verify the performance of the catalyst $\mathrm{H}_{3} \mathrm{PMo}_{12} \mathrm{O}_{40} / \mathrm{Nb}_{2} \mathrm{O}_{5}$, it was initially used to catalyze the transesterification of macaw palm oil. Ethanol and fusel oil were used as the acyl receptors. For both, a ratio of 1 oil:180 alcohol was used. Reactions lasted $6 \mathrm{~h}$. The final products of the reactions were qualitatively analyzed with $H$ NMR, with the results depicted in Figure 1. Additionally, the amounts of monoacylglycerol, MAG, and diacylglycerol, DAG, were quantitatively obtained with HPLC analysis, and the results are shown in Table 2, alongside the viscosities of the purified products.

According to the data shown in Table 2, high conversion results were obtained independently of the acyl receptor used. The high conversion of the transesterification reactions can also be confirmed by the low amounts of residual MAGs and DAGs (DAG was not even detected by HPLC analysis). Additionally, high conversion is also confirmed by the low amounts of viscosity. These results confirm the excellent efficiency of the catalyst, $\mathrm{H}_{3} \mathrm{PMo}_{12} \mathrm{O}_{40} / \mathrm{Nb}_{2} \mathrm{O}_{5}$ (ethanol or fusel oil). 


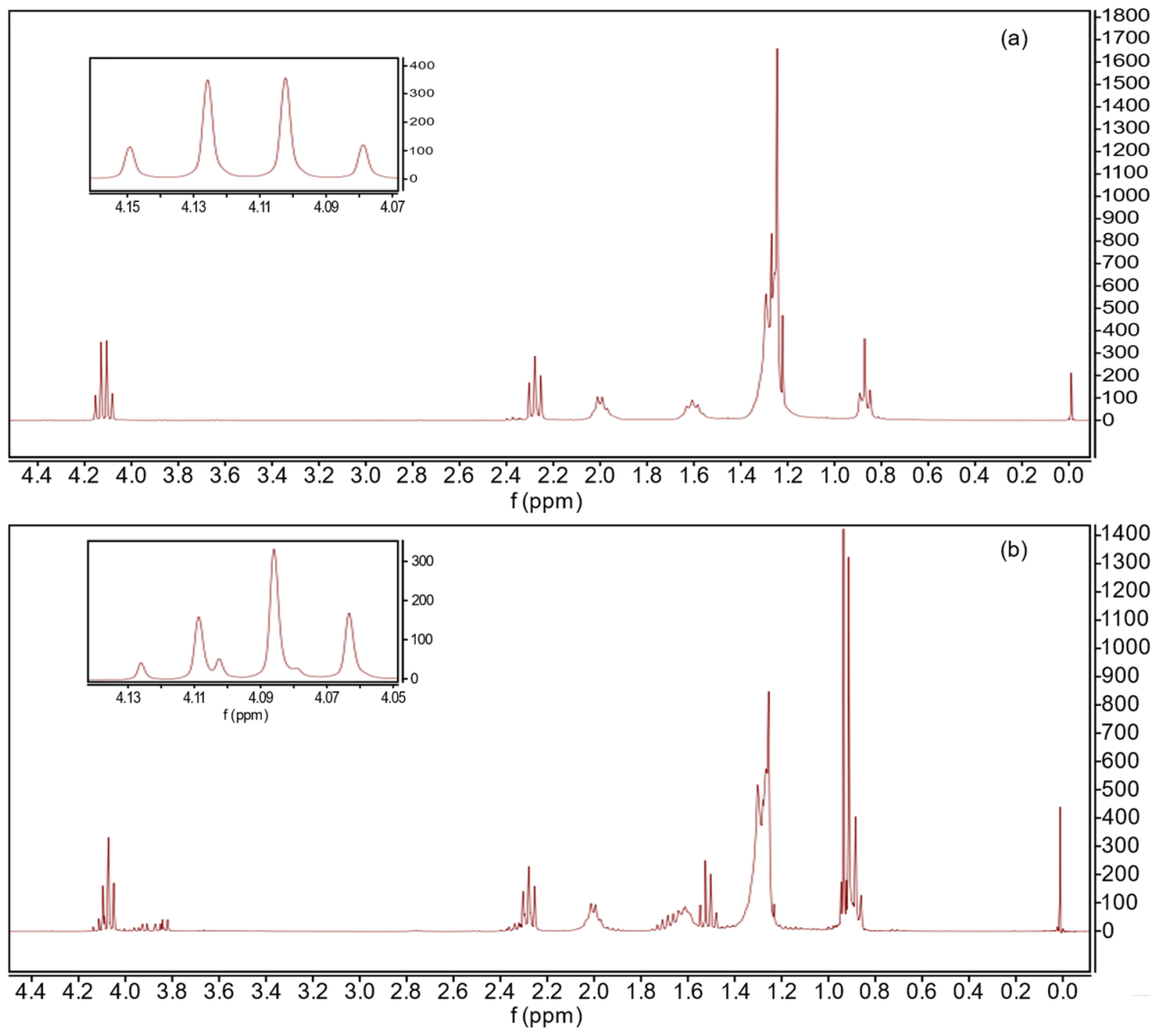

Figure 1. H NMR graphs on macaw palm oil transesterification reactions with different acyl receptors: (a) ethanol; (b) fusel oil and heteropolyacid supported by niobium as a catalyst.

Table 2. Efficiency of the transesterification of the macaw palm oil, using $\mathrm{H}_{3} \mathrm{PMo}_{12} \mathrm{O}_{40} / \mathrm{Nb}_{2} \mathrm{O}_{5}$ as a catalyst with two different acyl receptors.

\begin{tabular}{ccccc}
\hline Acyl Receptor & $\begin{array}{c}\text { Conversion } \\
\mathbf{( \% )}\end{array}$ & $\begin{array}{c}* \text { MAG } \\
(\mathbf{m} / \mathbf{m} \mathbf{\%})\end{array}$ & $\begin{array}{c}* \text { DAG } \\
(\mathbf{m} / \mathbf{m} \mathbf{\%})\end{array}$ & $\begin{array}{c}\text { Viscosity } \\
\left(\mathbf{m m}^{\mathbf{2}} \mathbf{s}^{-\mathbf{1}}\right)\end{array}$ \\
\hline Ethanol & 98.14 & 1.86 & $* * \mathrm{ND}$ & 4.9 \\
Fusel oil & 99.10 & 0.81 & $* * \mathrm{ND}$ & 5.5 \\
\hline
\end{tabular}

${ }^{*}$ MAG e DAG amounts are related to its mass content in the purified sample. ${ }^{* *}$ ND: not detected.

Once the catalyst's efficiency was verified, the next step was to evaluate its viability in direct transesterification using microbial biomass as feedstock. Thus, the obtained catalyst was evaluated via in situ transesterifications of the microalgae biomass (D. salina), using different acyl receptors: ethanol, butanol, isoamyl alcohol, and simulated fusel oil. The results of the analysis of these products are depicted in Figure 2 and Table 3.

Figure 2 presents the H NMR results obtained from the products of the in situ transesterifications of the $D$. salina biomass. Figure 2a presents a duplet peak, characteristic of ethyl esters (a product of in situ transesterification using ethanol as acyl receptor). Meanwhile, Figure $2 b, c$ have quadruplet peaks, characteristic of the presence of butyl and isoamyl esters (products of in situ transesterification reactions using butanol and isoamyl alcohol, respectively, as acyl receptors). The simulated fusel oil, on the other hand, is composed of a mixture of ethanol, butanol, and isoamyl alcohol. These products are qualitatively documented in Figure 2d. On the H NMR spectra, it can be observed in regions between 4.0 and 4.15 , the superposition of the quadruplet peak caused by the presence of ethyl esters, and the triplet peak caused by the presence of butyl and isoamyl esters. In the figure, the region is highlighted by the zoom area. 

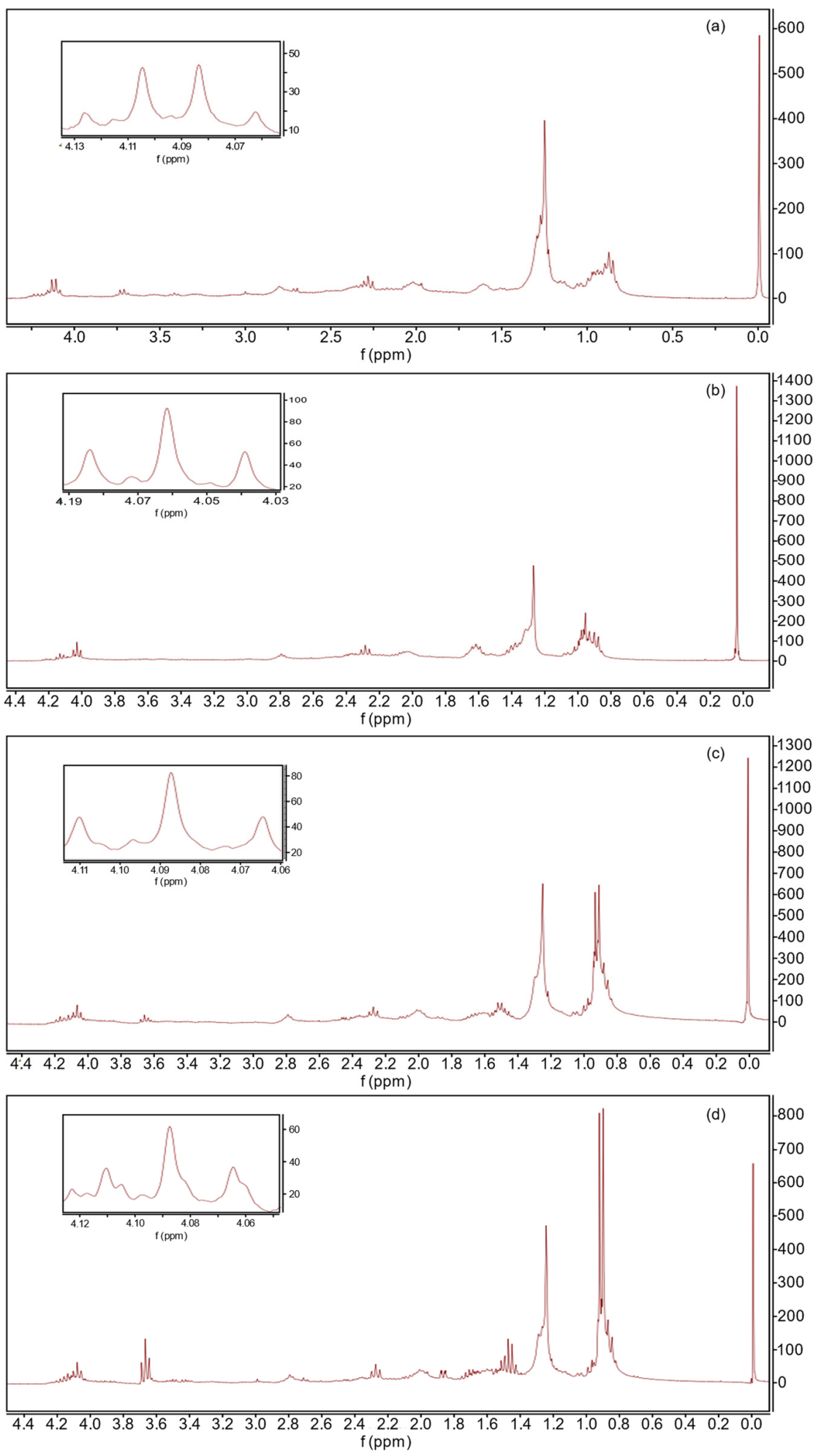

Figure 2. H NMR graphs of the products obtained from the in situ transesterifications of microalgae biomass (Dunaliella salina), using $\mathrm{H}_{3} \mathrm{PMo}_{12} \mathrm{O}_{40} / \mathrm{Nb}_{2} \mathrm{O}_{5}$ as a catalyst and as acyl receptors: (a) ethanol, (b) butanol, (c) isoamyl alcohol, (d) simulated fusel oil. 
Table 3. Efficiency of the in situ transesterifications of the microalgae biomass (Dunaliella salina) and Consortium (Scenedesmusobliquus/Mucor circinelloides) biomass, using $\mathrm{H}_{3} \mathrm{PMo}_{12} \mathrm{O}_{40} / \mathrm{Nb}_{2} \mathrm{O}_{5}$ as a catalyst.

\begin{tabular}{cccccc}
\hline & Alcohol & Conversion (\%) & ${ }^{*}$ MAG (m/m\%) & ${ }^{*}$ DAG (m/m\%) & Viscosity (mm $\mathbf{~ s}^{\mathbf{1}}$ ) \\
\hline & Ethanol & 92.94 & 1.55 & 5.51 & 6.2 \\
Dunaliella salina & Butanol & 97.60 & 1.14 & 1.26 & 4.8 \\
& Isoamyl alcohol & 97.40 & 2.60 & $* *$ ND & 4.9 \\
& Simulated fusel oil & 97.58 & 2.42 & $* *$ ND & 5.0 \\
\hline $\begin{array}{c}\text { Microalgae-fungus } \\
\text { consortium }\end{array}$ & Simulated fusel oil & 96.80 & 2.30 & 0.90 & 5.1 \\
\hline
\end{tabular}

* MAG e DAG amounts are related to its mass content in the purified sample. ${ }^{* *}$ ND: not detected.

According to Table 3, all reactions achieved good conversions, with low contents of residual MAG and DAG. Additionally, the obtained viscosities were low, ranging from 4.8 to $6.2 \mathrm{~mm}^{2} \mathrm{~s}^{-1}$. The lower viscosity $\left(4.8 \mathrm{~mm}^{2} \mathrm{~s}^{-1}\right)$, as expected, was obtained by the reaction with the greater yield (97.60\%). This result shows that $\mathrm{H}_{3} \mathrm{PMo}_{12} \mathrm{O}_{40} / \mathrm{Nb}_{2} \mathrm{O}_{5}$ is a promising catalyst for the transesterification of microalgae biomass.

Since a good reaction performance was observed using synthetic fusel oil, a transesterification reaction with microbial consortium biomass was performed, with equivalent results (conversion of $96.80 \%$ ).

\section{Discussion}

Based on obtained results, it is reasonable to say that the use of $\mathrm{H}_{3} \mathrm{PMo}_{12} \mathrm{O}_{40} / \mathrm{Nb}_{2} \mathrm{O}_{5}$, in direct transesterification, as a catalyst and fusel oil acyl receptor is promising when it comes to the generation of biolubricants from microbial biomass as feedstock. This statement is supported for two main reasons. The first is related to the use of an in situ transesterification, avoiding a costly extraction process. The traditional extraction process uses too much time, energy, water, and chemicals. Avoiding this step makes the process more practicable. Additionally, the process offers an alternative use for the chemical residues by-produced by fusel oil. The use of these residuals is very important and could make the process more sustainable.

There are few publications about the use of fusel oil as an acyl receptor in an in situ transesterification to obtain biolubricants. However, there are various scientific works that report the use of in situ transesterification to produce biodiesel from biomass $[27,28]$. Carvalho et al. [24], for instance, carried out direct transesterification reactions to obtain biodiesel from Mucor circinelloides biomass. A similar catalyst, $\left(\mathrm{H}_{3} \mathrm{PMo}_{12} \mathrm{O}_{40} / \mathrm{Al}_{2} \mathrm{O}_{3}\right)$, was applied, obtaining excellent reaction yields (from 96.1 to $98.5 \%$ ). Carvalho et al. [24] also reported low MAG and DAG contents for the transesterification procedure, similar to the results of the present work.

Carvalho et al. [29] also worked with $\mathrm{H}_{3} \mathrm{PMo}_{12} \mathrm{O}_{40} / \mathrm{Al}_{2} \mathrm{O}_{3}$ as a catalyst for a transesterification reaction. The authors evaluated its use in obtaining biodiesel from Mucor circinelloides biomass by means of regular and direct transesterification. According to their results, both methods achieved excellent yields (around 97\%) [29]. Such a result confirms that the suppression of the oil extraction process, using the in situ approach, would not reduce the reaction yield.

Da Silva et al. [4] also verified the feasibility of the production of biolubricants from D. salina biomass. The authors, however, used Burkholderia cepacia immobilized in $\mathrm{Nb}_{2} \mathrm{O}_{5}$ as their catalyst. Table 4 compares the results obtained by da Silva et al. [4] and this work. This table presents, for both sets of results, the transesterification yields, and the reaction times. 
Table 4. Efficiency of different heterogenic catalysts $\left(\mathrm{H}_{3} \mathrm{PMo}_{12} \mathrm{O}_{40}\right.$ and Lipase from Burkholderia cepacia (LBC), both supported in $\mathrm{Nb}_{2} \mathrm{O}_{5}$ ) in the transesterification using simulated fusel oil as acyl receptor.

\begin{tabular}{ccccc}
\hline Catalyst & Lipid Source & Time (h) & Conversion (\%) & Reference \\
\hline $\mathrm{LBC} / \mathrm{Nb}_{2} \mathrm{O}_{5}$ & D. salina microalgal oil & 120 & 90.00 & da Silva et al. [4] \\
$\mathrm{H}_{3} \mathrm{PMo}_{12} \mathrm{O}_{40} /$ & D. salina microalgal biomass & 6 & 97.58 & This work \\
$\mathrm{Nb}_{2} \mathrm{O}_{5}$ & Microalgae-fungus biomass & 6 & 96.80 & \\
\hline
\end{tabular}

The performance of the chemical catalyst proved to be efficient, as it demonstrated similar results with shorter reaction times, compared to the results of the biochemical catalyst. Da Silva et al. [4] obtained $90.0 \%$ conversion in $120 \mathrm{~h}$, while, conversely, the present work obtained higher conversions in only $6 \mathrm{~h}$. The conversions were $97.58 \%$ and $96.80 \%$, respectively, for microalgae and consortium biomass. The main difference in the obtained results, in fact, remains in the reaction time. Enzymes, such as the immobilized lipase LBC used by da Silva et al. [4], are good catalyst options among several applications due to their high reaction selectivity. Nevertheless, their main problem is that they need a much higher reaction time to achieve a good reaction conversion.

In terms of industrial production, this time reduction is vital, highly increasing the process' productivity and, subsequently, its viability.

\section{Conclusions}

Heteropolyacid $\left(\mathrm{H}_{3} \mathrm{PMo}_{12} \mathrm{O}_{40}\right)$ oxide-supported $\left(\mathrm{Nb}_{2} \mathrm{O}_{5}\right)$ is a feasible option for obtaining biolubricants from the transesterification of microalgae biomass for two main reasons: Firstly, it obtains high transesterification yields over brief time periods (up to $97.58 \%$ in $6 \mathrm{~h}$ of reaction). This means that the process not only achieves high reaction conversions, but also does it quickly, increasing its productivity and, respectively, its industrial viability. Secondly, its use of fusel oil residue in the process, without harming the final results. The reuse and proper disposal of chemical residues are of immense importance, both economically and environmentally. Furthermore, an alternative production method, using oleaginous biomass from a consortium of microalgae-filamentous fungi, demonstrated the same potential. Hence, the $\mathrm{H}_{3} \mathrm{PMo}_{12} \mathrm{O}_{40} / \mathrm{Nb}_{2} \mathrm{O}_{5}$ catalyst can make biolubricant production more attractive in the future.

Author Contributions: Conceptualization, S.M.F.E.Z., A.P.T.d.S., H.B.S.B., A.K.F.C., M.B.S., and P.C.M.D.R.; methodology, S.M.F.E.Z., G.A.P., E.H.B., A.K.F.C., H.B.S.B., A.P.T.d.S., and P.C.M.D.R.; software and formal analysis, S.M.F.E.Z., A.K.F.C., H.B.S.B., A.P.T.d.S., and E.H.B.; writing, review and editing, all authors. All authors have read and agreed to the published version of the manuscript.

Funding: This research was funded by São Paulo State Research Foundation (FAPESP, Brazil, grant numbers 2016/18909-3, 2016/10636-8, 2018/01386-3, and 2020/15513-7) and CNPq grant number 165390/2017-4. The APC was funded by FAPESP 2018/01386-3.

Institutional Review Board Statement: Not applicable.

Informed Consent Statement: Not applicable.

Data Availability Statement: Supporting data can be acquired privately from the authors or any member of the Biocatalysis Research Group of the Engineering School of Lorena (EEL-USP).

Acknowledgments: Authors are thankful to FAPESP (São Paulo State Research Foundation under process numbers 2016/18909-3, 2016/10636-8, 2018/01386-3, and 2020/15513-7) and to CNPq (process number 165390/2017-4). The authors would also like to thank the valuable efforts and contributions of Dr. Heizir F. de Castro (In memoriam).

Conflicts of Interest: The authors declare no conflict of interest. 


\section{References}

1. Bolina, I.C.A.; Gomes, R.A.B.; Mendes, A.A. Biolubricant Production from Several Oleaginous Feedstocks Using Lipases as Catalysts: Current Scenario and Future Perspectives. BioEnergy Res. 2021, 14, 1039-1057. [CrossRef]

2. Mobarak, H.; Mohamad, E.N.; Masjuki, H.; Kalam, A.; Al Mahmud, K.; Habibullah, M.; Ashraful, A. The prospects of biolubricants as alternatives in automotive applications. Renew. Sustain. Energy Rev. 2014, 33, 34-43. [CrossRef]

3. GVC Lubricants Market Size, Share \& Trends Analysis Report by Application (Industrial, Marine, Automotive, Aerospace), by Region (Asia Pacific, North America, Europe, MEA), and Segment Forecasts, 2021-2028. Available online: https://www. grandviewresearch.com/industry-analysis/lubricants-market (accessed on 10 December 2021).

4. Da Silva, A.P.T.; Bredda, E.H.; de Castro, H.F.; Da Rós, P.C.M. Enzymatic catalysis: An environmentally friendly method to enhance the transesterification of microalgal oil with fusel oil for production of fatty acid esters with potential application as biolubricants. Fuel 2020, 273, 117786. [CrossRef]

5. De Souza, E.C.; Belinato, G.; Otero, R.L.S.; Simêncio, É.A.; Augustinho, S.C.M.; Capelupi, W.; Conconi, C.; Canale, L.C.F.; Totten, G.E.; Rhee, I.-S.; et al. Thermal Oxidative Stability of Vegetable Oils as Metal Heat Treatment Quenchants. J. ASTM Int. 2012, 9, 1-30. [CrossRef]

6. Qiao, S.; Shi, Y.; Wang, X.; Lin, Z.; Jiang, Y. Synthesis of Biolubricant Trimethylolpropane Trioleate and Its Lubricant Base Oil Properties. Energy Fuels 2017, 31, 7185-7190. [CrossRef]

7. Bredda, E.H.; Da Rós, P.; Pedro, G.A.; De Castro, H.F.; Silva, M.B. Nannochloropsis gaditana and Dunaliella salina as Feedstock for Biodiesel Production: Lipid Production and Biofuel Quality. J. Adv. Biol. Biotechnol. 2018, 20, 1-10. [CrossRef]

8. Hawrot-Paw, M.; Ratomski, P.; Koniuszy, A.; Golimowski, W.; Teleszko, M.; Grygier, A. Fatty Acid Profile of Microalgal Oils as a Criterion for Selection of the Best Feedstock for Biodiesel Production. Energies 2021, 14, 7334. [CrossRef]

9. Patel, A.; Mu, L.; Shi, Y.; Rova, U.; Christakopoulos, P.; Matsakas, L. Single-Cell Oils from Oleaginous Microorganisms as Green Bio-Lubricants: Studies on Their Tribological Performance. Energies 2021, 14, 6685. [CrossRef]

10. Bredda, E.H.; da Silva, A.F.; Silva, M.B.; Da Rós, P.C.M. Mixture design as a potential tool in modeling the effect of light wavelength on Dunaliella salina cultivation: An alternative solution to increase microalgae lipid productivity for biodiesel production. Prep. Biochem. Biotechnol. 2020, 50, 379-389. [CrossRef]

11. Zorn, S.M.F.E.; Reis, C.E.R.; Silva, M.B.; Hu, B.; De Castro, H.F. Consortium Growth of Filamentous Fungi and Microalgae: Evaluation of Different Cultivation Strategies to Optimize Cell Harvesting and Lipid Accumulation. Energies 2020, 13, 3648. [CrossRef]

12. Valdovinos-García, E.M.; Barajas-Fernández, J.; de los Ángeles Olán-Acosta, M.; Petriz-Prieto, M.A.; Guzmán-López, A.; Bravo-Sánchez, M.G.; Patel, A.; Mu, L.; Shi, Y.; Rova, U.; et al. Isolation and characterization of two microalgal isolates from Vietnam with potential for food, feed, and biodiesel production. Energies 2020, 13, 1-19.

13. Kowal, P.; Ciesielski, S.; Otieno, J.; Majtacz, J.B.; Czerwionka, K.; Makinia, J. Denitrification Process Enhancement and Diversity of the Denitrifying Community in the Full Scale Activated Sludge System after Adaptation to Fusel Oil. Energies 2021, 14, 5225. [CrossRef]

14. Simsek, S.; Ozdalyan, B. Improvements to the Composition of Fusel Oil and Analysis of the Effects of Fusel Oil-Gasoline Blends on a Spark-Ignited (SI) Engine's Performance and Emissions. Energies 2018, 11, 625. [CrossRef]

15. Da Conceição, L.R.V.; Reis, C.E.R.; de Lima, R.; Cortez, D.V.; de Castro, H.F. Keggin-structure heteropolyacid supported on alumina to be used in trans/esterification of high-acid feedstocks. RSC Adv. 2019, 9, 23450-23458. [CrossRef]

16. Da Conceição, L.R.V.; Carneiro, L.M.; Giordani, D.S.; de Castro, H.F. Synthesis of biodiesel from macaw palm oil using mesoporous solid catalyst comprising 12-molybdophosphoric acid and niobia. Renew. Energy 2017, 113, 119-128. [CrossRef]

17. Chu, R.; Li, S.; Zhu, L.; Yin, Z.; Hu, D.; Liu, C.; Mo, F. A review on co-cultivation of microalgae with filamentous fungi: Efficient harvesting, wastewater treatment and biofuel production. Renew. Sustain. Energy Rev. 2021, 139, 110689. [CrossRef]

18. Darki, B.Z.; Seyfabadi, J.; Fayazi, S. Effect of nutrients on total lipid content and fatty acids profile of Scenedesmus obliquus. Braz. Arch. Biol. Technol. 2017, 60, e17160304. [CrossRef]

19. Cheung, S.L.; Allen, D.G.; Short, S.M. Specific quantification of Scenedesmus obliquus and Chlorella vulgaris in mixed-species algal biofilms. Bioresour. Technol. 2020, 295, 122251. [CrossRef]

20. Gatamaneni Loganathan, B.; Orsat, V.; Lefsrud, M.; Wu, B.S. A comprehensive study on the effect of light quality imparted by light-emitting diodes (LEDs) on the physiological and biochemical properties of the microalgal consortia of Chlorella variabilis and Scenedesmus obliquus cultivated in dairy wastewater. Bioprocess Biosyst. Eng. 2020, 43, 1445-1455. [CrossRef]

21. Rajendran, A.; Hu, B. Mycoalgae biofilm: Development of a novel platform technology using algae and fungal cultures. Biotechnol. Biofuels 2016, 9, 1-13. [CrossRef]

22. Guillard, R.R.L.; Lorenzen, C.J. Yellow-Green Algae with Chlorophyllide $C^{1,2}$. J. Phycol. 1972, 8, 10-14. [CrossRef]

23. Santos, F.D.; da Conceição, L.R.V.; Ceron, A.; de Castro, H.F. Chamotte clay as potential low cost adsorbent to be used in the palm kernel biodiesel purification. Appl. Clay Sci. 2017, 149, 41-50. [CrossRef]

24. Carvalho, A.K.F.; Bento, H.B.S.; Rivaldi, J.D.; de Castro, H.F. Direct transesterification of Mucor circinelloides biomass for biodiesel production: Effect of carbon sources on the accumulation of fungal lipids and biofuel properties. Fuel 2018, 234, 789-796. [CrossRef]

25. Cerón, A.A.; Boas, R.N.V.; Biaggio, F.C.; de Castro, H.F. Synthesis of biolubricant by transesterification of palm kernel oil with simulated fusel oil: Batch and continuous processes. Biomass Bioenergy 2018, 119, 166-172. [CrossRef] 
26. Carvalho, A.K.F.; Rivaldi, J.D.; Barbosa, J.C.; de Castro, H.F. Biosynthesis, characterization and enzymatic transesterification of single cell oil of Mucor circinelloides-A sustainable pathway for biofuel production. Bioresour. Technol. 2015, 181, 47-53. [CrossRef]

27. Cui, Y.; Liang, Y. Direct transesterification of wet Cryptococcus curvatus cells to biodiesel through use of microwave irradiation. Appl. Energy 2014, 119, 438-444. [CrossRef]

28. Indarti, E. Preparation of Biodiesel from Microalgae and Palm Oil by Direct Transesterification in a Batch Microwave Reactor. J. Phys. Conf. Ser. 2015, 622, 012040. [CrossRef]

29. Carvalho, A.K.F.; da Conceição, L.R.V.; Silva, J.P.V.; Perez, V.H.; de Castro, H.F. Biodiesel production from Mucor circinelloides using ethanol and heteropolyacid in one and two-step transesterification. Fuel 2017, 202, 503-511. [CrossRef] 